\title{
Ou-Testamentiese perspektiewe oor politieke en sosio-ekonomiese mag
}

\author{
J A LOADER
}

Hierdie artikel bied 'n oorsig oor 'n deel van die resultate van 'n ondersoek na die aspekte van menslike mag in die Ou Testament. Dit gaan dus om ' $n$ teologiese begripstudie. Hierdie term moet nader gekwalifiseer word. Wat 'teologies' betref, bestaan daar die benadering dat die Ou-Testamentiese (en die Nuwe-Testamentiese) teologie se taak ' $n$ omvattende beskrywing van die geheel van die Ou-Testamentiese geloof beslaan, of ' $n$ beskrywing van 'n aspek daarvan. Dit is dus ' $\mathrm{n}$ beskrywing van hoe die grootheid 'Ou-Testamentiese geloof' daar histories uitgesien het. Hierdie taak is sinvol as ' $n$ samevatting van wat ou Israel oor'n lang tyd in die geskiedenis geglo het. Maar dit is ' $n$ valse voorstelling dat hierdie historiese beskrywing die enigste taak van die Ou-Testamentiese teologie is (die sogenaamde 'biblische Theologie'). As ons alleen die grondstowwe mag lewer waarmee die dogmatiek en etiek moet werk, word die mees fundamentele teologiese arbeid verlaag tot die status van hulpwetenskap. As ons dus beskryf het hoe die geloof destyds daar uitgesien het, moet dit ook oorgaan in ' $n$ teologiese evaluering vir vandag. Die $\mathrm{Ou}$ Testament is deel van die klassieke model waartoe alles wat Christelik heet, in relasie staan. En daarom is dit die hanteerder van die $\mathrm{Ou}$ Testament se taak om die betrekking tussen ons moderne geloofsituasie en dié van die Ou Testament reg te ondersoek sodat hy kan sê wat daardie antieke materiaal vir vandag sê. Wat die woord 'begrip' betref: Die begrip 'menslike mag' maak deel uit van die groot OuTestamentiese geloofswêreld. Die begrip bestaan uit verskeie komponente ${ }^{1}$, en ons gaan aan twee hiervan aandag skenk - wat destyds sowel as vandag in besonder noue en aktuele verband tot mekaar staan.

\section{A Politieke mag}

Die verskillende literatuursoorte van die Ou Testament het almal 'n bydrae hieroor te maak - soms meer en soms minder dominant. In die wetlike literatuur vind ons die bekende politieke reëling van Deuteronomium 17:14-20. Die menslike inisiatief om 'n koning politieke mag te gee, word aanvaar, maar aan swaar voorwaardes onderwerp, naamlik dat die koning onderhewig is aan die wet van God nie perde en vroue mag vergader en homself oor sy broers mag verhef nie. 
Politieke mag is dus nie absoluut nie, maar onderhewig aan Gods mag. Verder lê hier 'n skerp kritiese element teenoor die politieke 'establishment' ${ }^{2}$. Juis die dinge wat die deuteronomiste in die politieke mag afkeur, is die dinge wat Salomo as deel van die oudoosterse politieke establishment in Israel ingevoer het ${ }^{3}$. Die deuteronomiste kon die politieke struktuur nòg negeer nòg beskou as ' $n$ besondere teken van Gods heilswil (Gerard Von Rad).

Die verhalende literatuur laat dieselfde basis te voorskyn tree. In I Samuel 8-12 (oor die instelling van die koningskap) word verskeie tradisies verenig sodat die eindresultaat soos volg lyk: Die monargie is deur die inisiatief van die mense verkies, maar God aanvaar dit. Daar sit egter ' $n$ kritiese ondertoon in, naamlik dat die nuwe politieke struktuur die teokrasie in gevaar stel en dus met reserwe aanvaar moet word. Hierdie kritiese voorwaardelikheid is skerp deur die deuteronomistiese verwerking onderstreep. Die deuteronomistiese en chronistiese geskiedwerke bou die kritiese element in die waardering van die politieke magstruktuur uit tot ' $n$ historiese beoordelingsnorm. Wanneer die maghebbers aan die voorwaardes van God voldoen, word hulle gunstig beoordeel en wanneer hulle nie voldoen nie, word hulle veroordeel. So word 'n geweldige teologiese beoordeling van die politiek geskep.

Die psalms van die Jerusalemse teologie is minder krities en besing die koning as die seun van God wat sy politieke mag by God kry (Ps 2). Maar ook hier ontbreek die element van die verantwoordelikheid van die koning nie. Waar sy mag besing word en voorbidding vir hom gedoen word (Ps 20), word sy onderhewigheid aan die eis van die gewer nie buite rekening gelaat nie. Psalm 21 stel dit as ' $n$ feit dat die koning op God vertrou, maar Psalm 72 spel die koninr se verantwoordelikhede uit: Armes en verdruktes sal hy red en sosio-ekonomiese geregtigheid beoefen. Dit word wel as stellige werklikheid uitgedruk, maar die onderliggende konsep van nie-absolute mag kom wel ooreen met die deuteronomistiese tradisie, met dié van nieabsolute mag kom wel ooreen met die deuteronomistiese tradisie, met dié verskil dat laasgenoemde nie die ideaal besing nie, maar die werklikheid ontleed.

Die wysheidsliteratuur is kalm en beredeneerd wanneer hy die politieke mag beoordeel. Enersyds word die gevaar van die koningsmag as'n feit uitgewys (Spr 16:14), maar die grondslag van goeie regering word ook aangedui: Regspraak (Spr 16:10), inskakeling by Gods orde (șe $d \bar{a} q \bar{a})$ en vermyding van boosheid (Spr 16:12), handhawing van sosiale geregtigheid (Spr 29:4), sosio-ekonomiese geregtigheid (Spr 29:14). Telkens is die politieke maghebber dus aan 'n hoër norm verantwoordelik - wat in die wysheidsliteratuur die orde van God is.

Nêrens kom die religieuse bemoeiing met aktuele politieke magte egter so onverbloemd en markant na vore as in die profetiese litera- 
tuur nie. Jesaja is hiervan die bekendste voorbeeld. Hy het hom telkemale ingemeng met beleidsake van verskillende regerings wat voluit op die terrein van die politiek lê. By hom vind ons ' $n$ aanvaarding van die messiaanse tradisie, dit wil sê dat die koning se politieke mag van God kom, maar dit is 'n dialektiese saak - dit eis naamlik van die maghebber onderhorigheid aan God en gehoorsaamheid aan Hom. Daarom kritiseer Jesaja op geloofsgronde die buitelandse beleid van Agas.

Wanneer sigbare bewys van die koning se geloof ontbreek, is hy'n oormoedige maghebber en kom onder die oordeel van God, wat 'n heidense buitelandse militêre mag teen die koning ${ }^{4}$ gebruik (Jes 7:18:8). Dieselfde gebeur later wanneer hy die buitelandse beleid van Hiskia kritiseer, naamlik sy pro-Egiptiese beleid, omdat dit weerstand beteken teen Gods oordeel waardeur Hy Juda aan militêre dominanse deur Assirië veroordeel het (Jes 30:1-5; vergelyk 30:15-17, 31:1-3).

Amos, Hosea en Miga kritiseer eweneens gangbare regeringsbeleid, byvoorbeeld oor militêre sake (Hos 10:13b-15) en sosio-ekonomiese onreg wat oogluikend toegelaat word (Am 2:6-16, 6:8, Mig 2:15). Later gebeur dieselfde by Jeremia, wat aanhoudend die oordeel oor die sosio-ekonomiese misstande uitspreek. Hy konfronteer die regering daarmee en kondig selfs skerper as Jesaja aan dat God die establishment met die instrument van 'n goddelose imperialistiese mag omver sal werp (Jer 21:1-10): God self veg teen sy volk saam met die heidense geweldenaars wat Hom nie eens erken nie. Die voorbeelde kan nog vermeerder word: Esegiël 11:1-13, waar nie net die koning nie, maar die hele Jerusalem se establishment onder die oordeel kom. So ook in die na-eksiliese tyd, byvoorbeeld Sagaria 7:7-14, waar God militêre onheil as straf vir sosio-ekonomiese verdrukking aanwend. Telkens - veral by Jesaja, Jeremia en Esegiël, tree die buitelandse mag selfstandig op, en word op sy beurt weer aan die profetiese kritiek onderwerp. Ons sal aanstonds meer aandag aan sosioekonomiese mag gee, sodat dit nie nou gewens is om daarop uit te brei nie. Hier sien ons dus dat sowel binnelandse as buitelandse sake in die lig van die Yahwehgeloof en die tradisie wat ons reeds in die wetlike literatuur kon sien, vertolk word, en dat daar uitdruklik mee ingemeng word.

Samevattend kan die volgende oor die eenheidsgetuienis van die Ou Testament oor politieke mag gesê word: Die feit van die politieke mag as sodanig word aanvaar. Dit word egter met reserwe gedoen. Die lig van die Yahwehgeloof en dus die eise daarvan vorm die basis vir die toetsing van die gebruik van die mag en die magstruktuur. Wanneer die toets wel geslaag word, word die regering goedgekeur. Die genoemde eise word soms algemeen gestel (gehoorsaamheid), maar baie dikwels gepresiseer (kultiese getrouheid en, oorweldi- 
gend, sosio-ekonomiese geregtigheid in die tradisie van die ou wette).

\section{B Sosio-ekonomiese mag}

Dit bring ons vanself by die sosio-ekonomiese aspek van menslike mag wat, soos ons pas gesien het, eng verbind is met binnelandse politieke verhoudings en die buitelandse konsekwensies daarvan. Weer vind ons ' $n$ verbasende eenstemmigheid in al die Ou-Testamentiese strata.

Al die groot wetsversamelings het eksplisiete verwysings na sosioekonomiese swakkelinge in die maatskappy en gee gewigtige voorskrifte. Die merkwaardige is die motiveringe wat as teologiese onderbou aan die voorskrifte gegee word. In die Bondsboek word finansiële hulp aan die armes voorgeskryf met die motivering dat God self genadig is. Dit is verbode om die weduwees en wese te verdruk, weer met die onderbou dat menslike barmhartigheid 'n refleks van Gods barmhartigheid moet wees. Daarby ook'n dreiging dat God die rolle sal omkeer as die sosio-ekonomiese maghebbers hulle wel leed aandoen. Die vreemdeling - wat nie tot die volk behoort het nie en geen burgerregte gehad het nie - mag nie in sy weerloosheid uitgebuit word nie. Hierdie keer is die motivering dat Israel self vreemdelinge was in Egipte en dus weet hoe dit voel. Tweërlei spreek hieruit: 'n Onmiskenbare humanitêre besorgdheid, en die nadoen van Gods liefde teenoor hulle. Dus gaan dit nie alleen om die uitvoer van die wet nie, maar om die gesindheid wat teologies in Gods liefde en die menswaardigheid van sosiale verworpelinge geanker is (Eks 22:20-26). Dieselfde basis is in die Heiligheidswet te vinde (Lev 19:9-10, 13, 15, 33-34). In die Deuteronomium word die sosio-ekonomiese besorgdheid tot ' $n$ omvattende welsynswet met teologiese grondslag uitgebrei: In die hele land mag daar geen arme wees nie omdat God die land met sy gawes aan al die inwoners gee. Gods gawe is die basis vir verdeling van rykdom - hoe kontroversieel dié wet ook in ons ore mag klink (Deut 15:1-11).

In die aartsvaderverhale word ekonomiese mag positief as gawe van God gewaardeer (Gen 24:1, 35, 26:12-14, 26:16, 28, 29, 30:25-34, 31:1ff., 32:10-13). Maar ook hier word die verantwoordelikheid van die 'haves' teenoor die 'have-nots' gevind (Neh 5:1-13).

Die motief van sosio-ekonomiese geregtigheid in die liriek is reeds hierbo by die bespreking van politieke verantwoordelikheid uitgewys. Vergelyk aanvullend ook Psalm 146:5-9 oor Gods optrede hieroor.

In die wysheidsliteratuur word die motief op verskillende maniere bespreek. Eerstens die feitelike stelling dat ekonomiese vermoë mag meebring (Spr 10:15 $)$. Tweedens dat verworwe besit nie buite God om bekom word nie, en dus ' $n$ seën is (Spr 10:22). Derdens word 
hierdie punt gekwalifiseer deur die opmerking dat nie àlle besit positief is nie: Word dit onregverdiglik bekom, is dit sonde - dus kan dit nie die seën van God wees nie (Spr 10:16). Vierdens is daar ook hier 'n uitgesproke simpatie vir die armes wat besonder veel en in sterk uitdrukkings voorkom: Spreuke 14:31 - wie sy medemens op sosio-ekonomiese gebied tekort doen, smaad God as skepper en die omgekeerde is erkenning van God; 19:17 - hulp aan armes is ' $n$ lening aan $\mathrm{God}^{7} ; 21: 13$ en 22:9 - waar vergelding vir optrede op hierdie terrein voorkom, en Spreuke 22:22-23 en 23:10-11 - waar die beskerming van die swakkes met Gods ingrype onderbou word.

Die profetiese literatuur bring hierdie hele tradisie, wat so sterk in die goddelike imperatief van die wetlike en wysheidskorpusse gestel word, tot sy groot hoogtepunt. Dit is hier so dominant omdat nie alleen die voorskrifte van Gods wil nie, maar die aktuele kritiek teen die werklikheid op grond daarvan na vore kom.

Jesaja striem die kultiese getrouheid as waardeloos omdat sosioekonomiese onreg teenoor die swakkelinge van die samelewing gepleeg word en sê die establishment daarom 'n omvattende oordeel aan (polito-militêr) - Jes 1:10-17, 21:28, 3:12-15, 5:8-10, 22-24, 10:1-4a ensovoorts. Jeremia doen presies dieselfde bv Jer 5:26-29, 21:11-14, 22:1-5, 13-19) en Esegiël eweneens (bv Eseg 22:23-31). Jesaja spreek sy oordeel vernaamlik oor die Jerusalemse elite uit, Jeremia spreek die politieke maghebbers aan en Esegiël die 'kerklike' leiers (wat 'n groot magsfaktor was), maar die meer algemene meervoud is ook teenwoordig, waar die volk as geheel dus aangespreek word. By Amos vind ons hierdie aanval op die sosio-ekonomiese magsmisbruik heel eerste onder die profete (Am 2:6-16) en by Miga is die algemeen geldende oordeel geweldig kras: God deel die erfdeel van sy volk aan ander uit wat Hom nie eens erken nie (Mig 2:1-5). Hierdie aantal voorbeelde pas in in die kompleks van die Yahwehtradisie wat ons in die ander korpusse teengekom het. Dus is die profetiese kritiek uit-en-uit konserwatief. Dit pas ook in by die politieke magsbeskouings: God verwerp sy eie volk, vernietig hulle politieke mag van bo tot onder deur buitelandse magte (ten spyte van hul heidendom en wreedheid) teen sy volk te gebruik. Jeremia gaan selfs so ver as om te stel dat die situasie so gode-onbehaaglik is dat sy volksgenote liewer na die heidense verwoesters moet oorloop (Jer 21:8-9).

Samevattend: Sosio-ekonomiese mag as sodanig word nie negatief beoordeel nie, maar wel onreg wat strydig is met die Yahwehgeloof en dus ' $n$ uiting van afwending van God ten spyte van kultiese suiwerheid. As polities relevante geloofsaspek word die aktualiteit 'teologies' beoordeel en skerp gekritiseer (profete), en as gesindheidsaak word die humane as die terrein van ware geloofsuitdrukking beskou (wette en profete). 


\section{Teologiese evaluering}

Hierdie kort oorsig dui daarop dat ons 'n dominante stratum in die 'Ou-Testamentiese teologie' voor ons het. Die beskrywing daarvan is egter nie vir die kerk genoeg nie. Ewe min die wegwerk daarvan ten gunste van ander $\mathrm{Ou}$-Testamentiese geloofsaspekte wat ons toevallig pas (byvoorbeeld die skepping of die verbond). Soos alles in die Bybel behoort hierdie stratum tot die klassieke model waartoe die kerk hom in betrekking stel (dit wil sê die Bybel). Daarom móét ons beoordeling vanuit die geheel van ons Godskennis hiermee rekening hou.

Natuurlik is dit so dat die moderne wêreld nie die politieke en sosio-ekonomiese strukture van die Bybel voetstoots kan oorneem nie. Die demokrasie is byvoorbeeld veel aanvaarbaarder as die absolute despotisme van 'n Israelitiese koning en, sê maar, lewensversekering as voorsorg vir weduwees en wese is veel beter as die oudIsraelitiese gebruike. Dit gaan ons om die herkenning van Gods wil ten opsigte van daardie antieke politiese en sosio-ekonomiese strukture, dus om die toepassing van die grondslag daarvan soos dit blyk uit die teologisering van die Ou-Testamentiese tradisiekorpusse oor die onderwerp. Hieruit kom myns insiens 'n aantal aktuele sake na vore:

1 Dit is nie alleen wettig nie, maar noodsaaklik dat kerk en teologie politieke strukture en programme beoordeel in die lig van die totaliteit van sy Godskennis. As dit is wat met politieke betrokkenheid bedoel word, moet die kerk polities betrokke raak in elke nuwe tydsgewrig. Ons kan nie ons taak met betrekking tot die regering afhandel met 'voorbidding vir die owerheid' nie. Ons mag hoeveel gewèttigde kritiek hê teen die SARK en die atrositeite waarby die WRK hom laat insleep het, maar ons sal 'n onbybelse eensydigheid begaan wanneer ons die kerk' se taak om krities te getuig oor die politieke sake van die dag prinsipieel of semi-prinsipieel ontken. Dit beteken nie party-politieke betrokkenheid nie, maar juis die teenoorgestelde. Die afstand en reserwe waarvan ons gehoor het, is 'n noodsaaklikheid vir kritiese toetsing en gevolglike teologies-gefundeerde kritiek wanneer die Bybelse toets nie deurstaan word nie.

2 Die probleem van politieke strukture is moeilik en brandend veral weens ongunstige konnotasies wat hierdie term van links bygekry het. In prinsipe kan 'strukturele onreg en geweld' wel plaasvind en sal die kerk hom daarteen moet uitspreek. Die vervanging van politieke strukture word nêrens in die Bybel bepleit nie, maar wel die 'hervorming' van sulke strukture as hulle verrot geword het ${ }^{10}$. Die politieke struktuur van byvoorbeeld Aminese Uganda ${ }^{11}$ kan in geen opsig die Bybelse toets deurstaan nie. Daarom sal die kerk in 
Uganda (en daarbuite) hom vir die verandering daarvan moet uitspreek. Hoe? - Sekerlik nie met wedergeweld nie. Die kerk kan nie dit wat hy afkeur, help verander met dieselfde afgekeurde middel nie. Daarom kan ons die WRK hieroor nie gelyk gee nie. Maar die kerk kan en moet in so 'n situasie met 'n teologies gemotiveerde, kritiese getuienis kom wat op die politieke werklikheid afgestem is.

3 God kan nooit aan die kant van watter politieke saak ook al ingespan word nie. Sy volk is nooit vanweë die suiwerheid van hul belydenis gevrywaar van sy oordeel nie. Wanneer die politieke werklikheid nie uiting gee aan sy wil nie, kan $\mathrm{Hy}$ (nie 'móét $\mathrm{Hy}^{\prime}$ nie) die polito-militêre wêreldgebeure teen sy eie volk gebruik. Hy kan die atrositeite van watter heidense geweldenaars ookal gebruik sonder om hul dade te legitimeer deur dit te wil (dit wil sê sulke instrumente bly nog selfstandig en vir hul eie optrede verantwoordelik - egter sonder dat God daaroor beheer verloor). Daarom kan ydellike gebruik van Gods naam baie maklik plaasvind wanneer Hy vir 'ons saak' opgekommandeer word teen die bose bedreigers - sonder dat daar na binne gekyk en die lig van sy wil op die interne politieke toneel gewerp word - veral wat sosio-ekonomiese geregtigheid betref.

4 Die kerk moet hom noodwendig met die sosio-ekonomiese situasie in sy wêreld bemoei. Hier dreig ook eensydigheid. Wanneer ons met reg kritiek uitspreek teen 'versosialisering', 'horisontalisme' en (verouderd) 'social gospel', dan kan dit die oorweldigende klem kry en tot ' $n$ de facto ontkenning lei van die Bybelse eis van sosio-ekonomiese geregtigheid. Dié is ' $n$ dominante terrein waarop die geloof en suiwere belydenis se opregtheid tot uiting kom. Die teologiese grondslag daarvan is juis dat die humane, die erkenning van en respek vir menswaardigheid en menseregte (watter konnotasie Carter ookal daaraan gee) 'n uitingsvorm is van dié geloof waardeur ons voor God geregverdig word en die lewe by Hòm ontvang.

5 Die linkse slagspreuk dat besit diefstal is, is onhoudbaar. Die idee van besit as Gods gawe is egter ambivalent. Alles wat mense besit, hoef nie noodwendig sy gawe te wees waarvoor hulle Hom mag dank nie. Wanneer besit bekom word op 'n wyse wat bots met Gods wil (soos ons gesien het) is dit nie sy gawe nie. Byvoorbeeld wanneer korrupsie in een of ander Suid-Amerikaanse diktatuur tot verryking van' $n$ minderheid en verarming of verknegting van andere lei, kan sulke mense God nie dank vir hul daaglikse fyngebak nie. Dit toon dat hierdie saak op korporatiewe (sogenaamde 'strukturele') sowel as indiwiduele vlak geld. Enige sisteem of struktuur wat mense die geleentheid tot sosio-ekonomiese verwesenliking ontneem, staan veroordeel voor God net soos ' $n$ indiwidu wat sy medemens se besit of reg tot besit onregmatiglik inkort. 
Ek het probeer om die aktualiteit van 'n grondliggende Bybelse stratum met 'veilige' voorbeelde te illustreer. Dit is bedoel om die prinsipiële aspek van die onderwep vry te hou van omstredenhede in ons Suid-Afrikaanse situasie. Dat ons ons egter teologies daarmee moet besig hou, is seker. Dit gaan wesenlik om balans - dat ons ons naamlik bevry van die impasse waarin die pendulumeffek van die horisontaal-vertikaal-debat die teologie laat beland het.

\section{VOETNOTAS}

1 Generies, militêr, polities, sosiaal, sosio-ekonomies, fisies.

2 Die woord word hier gebruik sonder sy hedendaagse byklank.

3 I Kon 10:25, 11:1-11, 12:4.

4 Nie teen die volk nie, dus wel teen die politieke establishment.

5 Vergelyk verder die sosio-ekonomiese reëlings in verband met die jubeljaar en die lossingsreg (Lev 25).

6 Vergelyk ook Spreuke 14:20, 18:23, 22:7.

7 God as skepper en die skepsel dus in afgeleide sin as 'n waardige figuur - 'n sterk teologisering van die onderwerp (vergelyk ook 19:17 vir laasgenoemde).

8 Sosio-ekonomiese geregtigheid is juis ' $n$ aspek van die $\mathrm{Ou}$-Testamentiese verbond en dus vervleg daarmee!

9 'Kerk' beteken hier die kerk op al sy vlakke en al die gestaltes waarin hy homself in die wêreld kenbaar maak - van sy amptelike vergaderings tot sy ampsdraers en lidmate.

10 Die verandering daarvan met die tyd (evoluering) is ' $n$ ander saak.

11 Hierdie artikel is geskryf vóór die val van Idi Amin. 